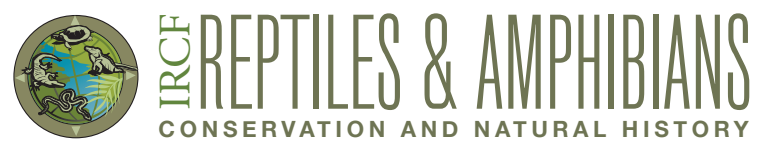

\title{
First Records of the Stout Four-eyed Frog, Pleurodema brachyops (Cope 1869) on St. Martin
}

Jöran Janse ${ }^{1}$, Elfriede Schotsmans ${ }^{1}$, Mark Yokoyama ${ }^{2}$, Julien Chalifour ${ }^{3}$, and Timothy P. van Wagensveld ${ }^{1}$

${ }^{1}$ Reptile Amphibian and Fish Conservation, The Netherlands (RAVON), Toernooiveld 1, 6525 ED Nijmegen, The Netherlands (j.janse@ravon.nl) ${ }^{2}$ Association Les Fruits de Mer, Grande-Case, St. Martin

${ }^{3}$ Réserve Naturelle Nationale de Saint-Martin, Grande-Case, St. Martin

Photographs by the senior author.

T

'he Stout Four-eyed Frog (Pleurodema brachyops) is native to the northern South American and Central American nations of Guyana, northern Brazil (Roraima State), Venezuela (including Isla Margarita), eastern and northern Colombia into the Pacific lowlands of Panama from Azuero to central Panama, and Aruba (La Marca et al. 2010). The species is considered introduced on Curaçao, Bonaire, and Klein Bonaire (Hummelinck 1940; van Buurt 2005). Herein we present the first observations of $P$. brachyops on both the Dutch and French sides of Sint Maarten/St. Martin, where it is the fifth anuran species to be introduced and established after the Lesser Antillean Frog (Eleutherodactylus johnstonei), Martinique Frog (Eleutherodactylus martinicensis), Cuban Flat-headed Frog (Eleutherodactylus planirostris), and Cuban Treefrog (Osteopilus septentrionalis) (Powell et al. 2015). Stout Four-eyed Frogs were almost certainly introduced to the island as a consequence of ornamental plant imports (e.g., Powell et al. 2011).

The first Stout Four-eyed Frogs were discovered on 24 October 2015 in the Sucker Garden area, specifically around

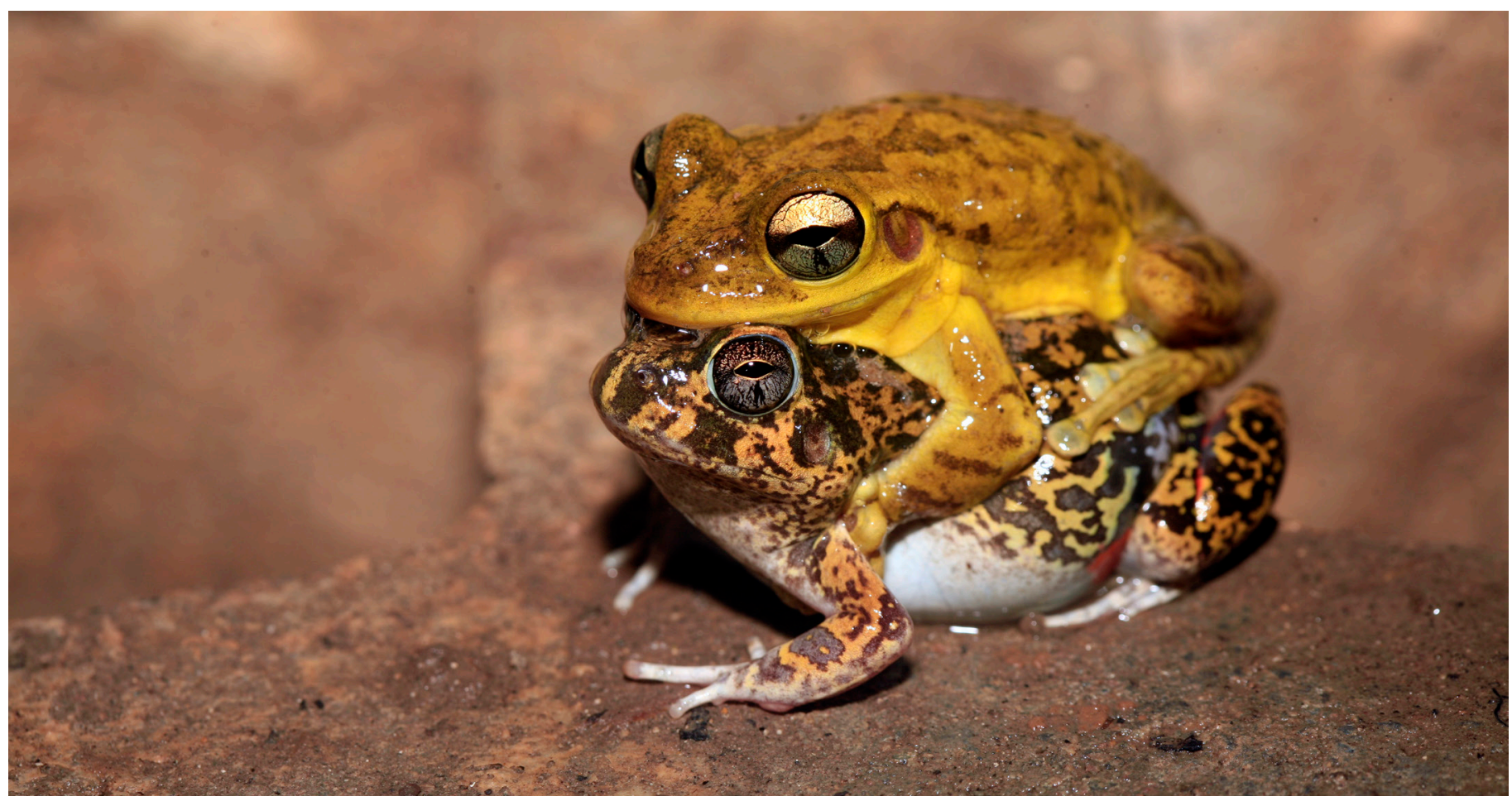

Fig. 1. Amplexus of a male Cuban Treefrog (Osteopilus septentionalis) and a female Stout Four-eyed Frog (Pleurodema brachyops) in Philipsburg, Sint Maarten. 
a hotel called Vicky's Keys $\left(18.034802^{\circ} \mathrm{N},-63.037181^{\circ} \mathrm{W}\right.$; WGS 84) in Philipsburg, by Elfriede Schotsmans and Jöran Janse. In 2017, further sightings were in Grand-Case $\left(18.104966^{\circ} \mathrm{N},-63.052418^{\circ} \mathrm{W}\right.$; WGS 84) and in the French Quarter $\left(18.0799970^{\circ} \mathrm{N},-63.026434^{\circ} \mathrm{W}\right.$; WGS 84) by Mark Yokoyama, and in the northeastern area known as Cul-deSac $\left(18.0991667^{\circ} \mathrm{N},-63.025833^{\circ} \mathrm{W}\right.$; WGS 84) by Julien Chalifour. We believe these are the only sightings of these frogs on the island. Several individuals were observed at each of the four sites, which suggests that the species is widely distributed in suitable habitat.

Initial observations of $P$. brachyops followed heavy rainfalls when frogs were heard calling from a flooded basement that was under construction. Interestingly, a male Cuban Treefrog was observed in amplexus with a female Stout Foureyed Frog (Fig. 1). In a puddle outside the building, a pair of $P$. brachyops in amplexus were making a foam nest, which confirms reproduction by this species on St. Martin (Fig. 2). Furthermore, during a nightly walk in the neighborhood that same evening, an adult Stout Four-eyed Frog was encountered on a road and a foam nest was found in a partly flooded meadow. The owners of the Vickey's Keys Hotel knew about the species from Curaçao but were uncertain how long they had known about the species on St. Martin.

We strongly encourage an island-wide survey to determine the species' distribution beyond the current adventitious observations. We also suggest a study to examine the potentially negative effects that these frogs could have as predators and or prey of native fauna. Stout Four-eyed Frogs exhibit deimatic behavior to discourage predators, using inguinal macroglands that resemble eyes (Martins 1989; Fig. 3). However, if this tactic proves unsuccessful, and a predator bites the frog, it will release a toxic secretion (Lenzi-Mattos et al. 2005). What consequences these toxins could have on potential predators is unknown.

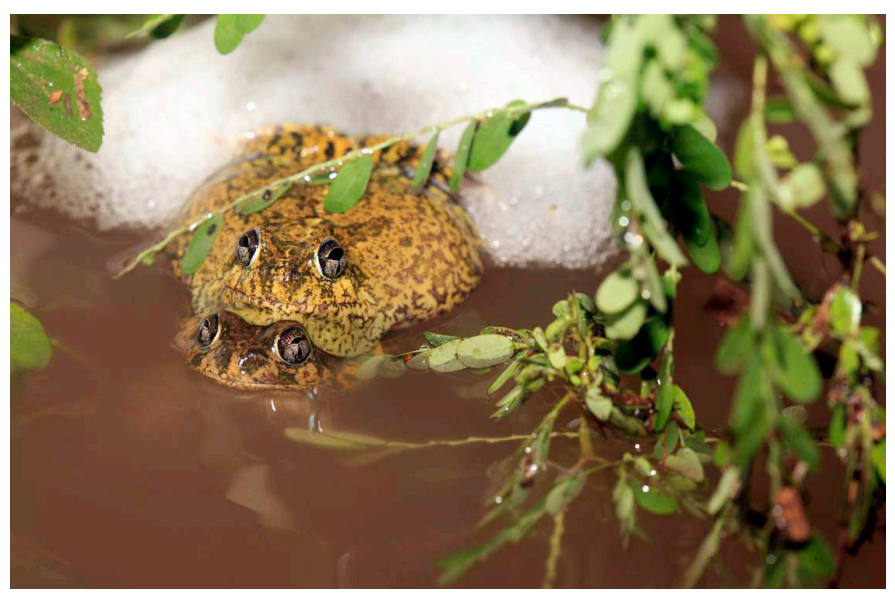

Fig. 2. Stout Four-eyed Frogs (Pleurodema brachyops) in amplexus making a foam nest in Philipsburg, Sint Maarten.



Fig. 3. A Stout Four-eyed Frog (Pleurodema brachyops) from Philipsburg, Sint Maarten, engaged in deimatic behavior by exposing two inguinal poison glands that resemble eyes.

Furthermore, during a herpetological inventory on St. Eustatius in 2015, a resident mentioned toads coming out of the ground after heavy rainfall. These could be Stout Foureyed Frogs since the considerable traffic in goods between St. Martin/Sint Maarten and neighboring islands is probably responsible for the introduction of other exotic species (e.g., Cuban Treefrogs and Green Iguanas, Iguana iguana) on Saba (Powell et al. 2015). Therefore, we propose thorough ongoing searches on St. Eustatius and Saba for P. brachyops and other introduced species.

\section{Acknowledgements}

We thank the owners and staff of Vicky's Keys for information and a pleasant stay.

\section{Literature Cited}

Hummelinck, P.W. 1940. Studies on the fauna of Curaçao, Aruba, Bonaire, and the Venezuelan Islands. No. 2. A survey of the mammals, lizards and molluscs. Studies on the Fauna of Curaçao and Other Caribbean Islands 1: 59-108.

La Marca, E., F. Solís, R. Ibáñez, C. Jaramillo, Q. Fuenmayor, R. Reynolds, M. Trefaut Rodrigues, A. Mijares, and R. MacCulloch. 2010. Pleurodema brachyops. The IUCN Red List of Threatened Species 2010: e.T57283A11599287.

Lenzi-Mattos, R., M.M. Antoniazzi, C.F.B. Haddad, D.V. Tambourgi, M.T. Rodrigues, and C. Jared. 2005. The inguinal macroglands of the frog Physalaemus nattereri (Leptodactylidae): structure, toxic secretion and relationship with deimatic behaviour. Journal of Zoology 266: 385-394.

Martins, M. 1989. Deimatic behavior in Pleurodema brachyops. Journal of Herpetology 23: 305-307.

Powell, R., R.W. Henderson, M.C. Farmer, M. Breuil, A.C. Echternacht, G. van Buurt, C.M. Romagosa, and G. Perry. 2011. Introduced amphibians and reptiles in the greater Caribbean: Patterns and conservation implications, pp. 63-143. In: A. Hailey, B.S. Wilson, and J.A. Horrocks (eds.), Conservation of Caribbean Island Herpetofaunas, Volume 1: Conservation Biology and the Wider Caribbean. Brill, Leiden, The Netherlands.

Powell, R., R.W. Henderson, and J.S. Parmerlee, Jr. 2015. The Reptiles and Amphibians of the Dutch Caribbean: St. Eustatius, Saba, and St. Maarten. Second edition, revised and expanded. Nature Guide Series No. 004. Dutch Caribbean Nature Alliance, Bonaire, Dutch Caribbean.

van Buurt, G. 2005. Field Guide to the Amphibians and Reptiles of Aruba, Curaçao and Bonaire. Edition Chimaira, Frankfurt a/Main, Germany. 